$\overline{\text { 文 }}$

\title{
Bacillus 属胞子のオゾン殺菌作用に及ほ 含硫化合物の影響十
}

内 藤 茂 三*志 賀 一 三*

Effect of Sulfur Compounds on Germicidal Properties of Ozone to Bacillus Spores

(Studies on Utilization of Ozone in Food Preservation Part II)

\author{
Snigezo NaIto* and Ichizo SHIGA* \\ * Food Research Institute, Aichi Prefectural Government, \\ 2-1, Shinpukuzi-cho, Nishi-ku, Nagoya, 451
}

\begin{abstract}
This paper describes the effect of sulfur compounds, i. e. diallyldisulfide (DADS), diallylsulfide (DAS) and hydrogen sulfide, on the germicidal activity of ozone to spores of Bacillus coagulans IAM 1115 and Bacillus stearothermophilus IAM 1035. Spore suspensions $\left(10^{7} \sim 10^{8} / \mathrm{ml}\right)$ were treated with ozone $(0.5 \mathrm{mg} / \mathrm{l})$ under a flow rate of $1455 \mathrm{ml} / \mathrm{min}$ at $20^{\circ} \mathrm{C}$. Results were as follows: (1) When $B$. coagulans spores were exposed to ozone, germicidal effect was significantly enhanced by the presence of DADS or DAS. But, the effect was not demonstrated for B. stearothemophilus spores. (2) DADS or initiated spore germination. It seem that the increase of ozone sterilziation in presence of DADS or DAS depends on spore germination. (3) Germicidal activity of ozone exposure was decreased at the presence of $20 \mathrm{mM}$ hydrogen sufide, but increased at the presence of $2 \mathrm{mM}$ or $0.2 \mathrm{mM}$ hydrogen sulfide. This 'result is considered to have been caused by the difference of residual ozone concentration and final $\mathrm{pH}$.
\end{abstract}

(Received May. 2, 1981)

オゾンの殺菌効果に及ぼす影響因子についての報告は

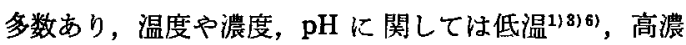

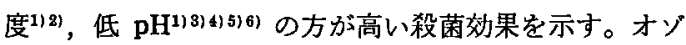
ン殺菌の特徵は被殺菌微生物の種類により著しく殺菌効 果が異なる。的一般にオソンは有機物の存在下でも殺菌 作用を示すが，微生物に污染された食品原材料をオゾン 殺菌した場合は，微生物を単独に同一条件で殺菌した場 合よりも殺菌効果が劣る6こ。ような現象がおこる原 因としては，微生物の存在部分へのオソンの浸透が姑げ られるとか, あるいは原材料によるオソンの吸着や化学 反芯による有勃オゾン濃度の低下等が考えられる。しか
し不安定な有機化合物，すなわち大気中の不飽和結合を 有する有真物質や，フェノール，硫化水素，メルカプタ ン，インドール，スカトールなどに原因する色や真気は オソンにより分解されるが, その場合の殺菌力も強大で あるのでオゾンが工場廃水処理の外，特に防臭，殺菌な ど環境衛生上応用されるようになってきた。前報6にお いて Bacillus 属胞子に対してオゾン殺菌を行った場合, ニンニク粉末 $(0.2 \sim 1.0 \%)$ を添加するととにより殺菌 力が増加することを認めた。またニンニク入の加熱包装 味付け肉学 $5^{\circ} \mathrm{C}$ と $30^{\circ} \mathrm{C}$ で保存した場合， $30^{\circ} \mathrm{C}$ の方が 生菌数が圧倒的に少ないことが経験的に知られている。 
これは明らかにニンニクの含硫化合物の静菌効果に由 来すると考えられる。DoLD ら”は B. subtilis に対して ニンニクはこの菌の発育を阻止することを報告してい る。また CAVALLITO ら のみをとりあげその抗菌性を調べたところ，アリシンの 作用は殺菌というよりも静菌的であり，グラム陽性，陰 性を問わず効力を有しているとしている。

そこで今回，前報6でオン゙ン殺菌において比較的抵抗 力が認められた B. coagulans, B. stearothermophilus 胞子を用いて，ニンニク具の主成分であるジアリルジサ ルフォィド (DADS), ジフリルサルフォィド (DAS) 及 びニンニクの揮発性成分の一種である硫化水素の共存殺 菌勃果を検討したので報告子る。

\section{実 験 方 法}

\section{1. 供試菌株}

供試菌にはオゾンに刘して抵抗力の大きい'B. coagulans IAM 1115 及び $B$. stearothermophilus IAM 1035 の胞子を用いた。生菌数測定用及び胞子形成用培 地の調製並びに培養方法，胞子㲘濁液の調製は前報 ${ }^{61}$ と 同じである。

\section{2. オ・゙ン処理装置}

オゾン処理装置はほほ前報6) と同じであるが，試料好 理瓶の次に硫化水素を吸収させるために $1 \%$ 炭酸力ドミ ウム溶液を入れたガス洗浄瓶を接続させ，さらにオン゙ン 処理により発生が予想された二酸化イオウを吸収させる ために 3 \%過酸化水素水液を入れたガス洗浄瓶を接続さ せた。処理方法及び処理条件は前報6と同しである。

\section{3. 胞子の発芽試験}

胞子眊濁液 $\left(1.5 \times 10^{8} / \mathrm{ml}\right)$ は $100^{\circ} \mathrm{C}$ て 10 分間熱処理 後, $0.1 \%$ 塩化カリウム含有トリスー塩酸䌅衝液 $(20 \mathrm{~m}$ M, pH 7.4) に整濁させ DADS, DAS (50 mM, $5 \mathrm{mM}$, $0.5 \mathrm{mM})$ ，硫化水素 $(20 \mathrm{mM}, 2 \mathrm{mM}, 0.2 \mathrm{mM})$ 及び L-, D-ア ラニン $(10 \mathrm{mM})$ を添加後, $30^{\circ} \mathrm{C}$ で発芽させ O.D. $(660 \mathrm{~nm})$ の低下を測定した。

\section{4. 供試共存物質}

硫化水素は硫化ナトリウム $20 \mathrm{~g}$ に塩酸 (1: 1) $500 \mathrm{ml}$ を加光，発生する硫化水素を蒸留水に溶解させたものを 原液として使用し，濃度の測定は JIS"1により求めた。 その際溶液扩よび容器はすべて氷水中で洽却しながら稀 䣋操作を行った。DADS, DAS は市販品（東京化成(株) 製）を用いた。なおガスクロマトグラフ法による標準物 質の保持時間測定用に二酸化イオウは，メタ重覀硫酸力 リウムに硫酸（1：1）を加えて発生させ，硫化カルボ二
ルは POKORNY10) の方法で発生させたものを用いた。

\section{5. 含硫化合物の測定}

試料瓶中の含硫化合物の測定はガスクロマトグラフ法 (操作条件は Table 1 を参照) により行った。すなわち オソン処理試料瓶（ガス洗浄瓶）の各処理時間每に一。 ドスペイスガスは $0.5 \mathrm{ml}$, 試料液は $1 \sim 2 \mu 1$ 崖探取し炎 光光度検出器 (FPD, S-フィルター) 付ガスクロマトグ ラフによって分析した。なおモニターとして FIDを用 いた。

Table 1 Analytical conditions for gas chromatography and retention times of sulfur compounds

\begin{tabular}{ll}
\hline \hline Instrument & Shimazu 6 A \\
Column & $1,2,3$ TCEP $25 \%$ shimalite $(80 / 100 \mathrm{mesh})$ \\
& AW-DMDS in glass col. ( $33 \mathrm{~mm} \times 3 \mathrm{~m})$ \\
Carrier gas & $50 \mathrm{ml} / \mathrm{min}\left(\mathrm{N}_{2}\right)$ \\
Col. témp. & $70 \sim 135^{\circ} \mathrm{C}\left(3^{\circ} \mathrm{C} / \mathrm{min}\right)$ \\
$\mathrm{H}_{2}$ & $40 \mathrm{ml} / \mathrm{min}$ \\
Air & $40 \mathrm{ml} / \mathrm{min}$ \\
Detector & FPD $(\mathrm{S} \mathrm{channel})$, FID monitor \\
Det. temp. & $150^{\circ} \mathrm{C}$ \\
Inj. temp. & $150^{\circ} \mathrm{C}$ \\
\hline
\end{tabular}

Col. temp. $70^{\circ} \mathrm{C}$ Col, temp. $70^{\circ} \sim 135^{\circ} \mathrm{C}\left(3^{\circ} \mathrm{C} / \mathrm{min}\right)$ Carbonyl sulfide $1.09 \mathrm{~min}$ Diallylsulfide $\quad 15.15 \mathrm{~min}$ Hydrogen sulfide $1.21 \mathrm{~min}$ Diallyldisulfide $35.21 \mathrm{~min}$ Sulfur dioxide $\quad 2.51 \mathrm{~min}$

ヘッドスペイスガスの分析の場合は,カラム温度 $70^{\circ} \mathrm{C}$ で行い, 試料液の分析は $70^{\circ} \mathrm{C} り 3^{\circ} \mathrm{C} / \mathrm{min}$ の䒜温速 度で $135^{\circ} \mathrm{C}$ ぜカラム温度を上昇させた。以上の操作に おける硫化カルボニル，硫化水素，二酸化イオウ， DADS, DAS の保持時間岩 Table 1 に示した。含硫化 合物量の測定は，島津デジタルインテグレーター (ITG4 A）のビーク高とあらかじめ作成した検量線より求め た。なお $1 \%$ 炭酸カドミウムに吸収された硫化水素法 JIS ${ }^{91}$ の方法により，3\% 過酸化水素水に吸収された二 酸化イオウは N/50 水酸化ナトリウムによる滴定法によ り冰めた。

\section{6. 赤外吸収スペクトル}

四塩化炭素, ペンゼン, 水に DADS, DAS を溶解又 は㲘濁後，オゾン処理を行い日本分光 IRA-2 型を用い て分析した。

\section{実験結果及び考察}

\section{1. オゾン殺菌作用に及ぼす共存 DADS 及び DAS の影響}


(1) オゾン処理による DADS, DAS の殺菌促進効果 香辛料およびその精油の抗菌力"181112)については， かなり古くから知られており，現在でも香辛料の有して いる防腐効果, 静菌効果, 細菌の増殖発育抑制勏果など を利用して加工食品の保存, 肉類の保存などに利用され ている。しかし精油のこのような性質を食品に応用し， 食品の保存性を高めているという例はほとんどなく，現 在検討されはじめているという状態である。そこで今 回，DADS 及び DAS の共存下でのオン゙ン殺菌作用を 検討した。

この場合, 水溶液中に紫濁した胞子 $\left(1.2 \times 10^{7} / \mathrm{ml}\right)$ に ペンゼンに溶解した各濃度の DADS, DAS を $1 \mathrm{ml}$ 混 合 $(300 \mathrm{ml}$ ガス洗浄瓶内) 紫濁したもの及び胞子単独 (1 ml ヘンゼン含有) のるのを実験方法に記した方法で 通気処理及びオゾン処理を行った。1例として $5 \mathrm{mM} の$ DADS, DAS 共存下での通気処理及びオゾン処理 1 時間 後の結果を Fig. 1 に示した。B. coagulans 胞子単独 の場合，オゾン殺菌効果 $\left(\log \mathrm{N}_{0} / \mathrm{N}: \mathrm{N}_{0}\right.$, 初発胞子数; $\mathrm{N}$, 殺菌処理液の生存胞子数）が 2.71 であるのに対し, 胞子惩濁液に DADS, DAS を混合した通気の場合， $10 \mathrm{~g}$ $\mathrm{N}_{0} / \mathrm{N}$ がそれぞれ 2.92，2.18 であり，オゾン処理の場 合はそれぞれ 4.38，4.00であった。

DADS, DAS が通気処理においても明らかに殺菌作

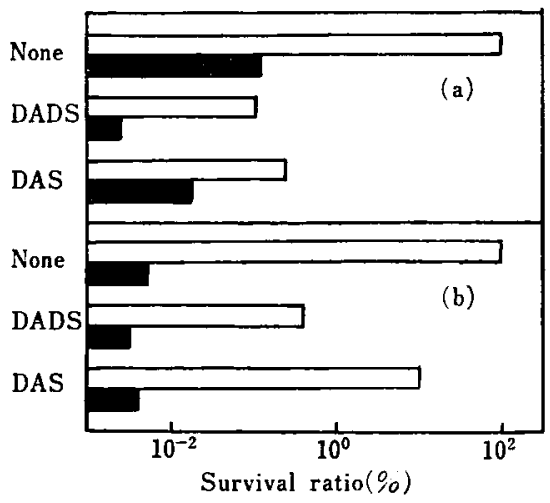

Fig. 1 Effect of DADS and DAS on sporicidal activity of ozone

Spores in a test gas wash bottle, spores coexisting with $5 \mathrm{mM}$ of DADS and DAS in a vial, and spores suspensions at $20^{\circ} \mathrm{C}$ were treated by ozone of $0.5 \mathrm{mg} / 1$ under a flow rate of $1455 \mathrm{ml} / \mathrm{min}$ for $60 \mathrm{~min}$, and control was airated in the same condition.

(a) B. coagulans IAM 1115 spores $(1.2 \times$ $\left.10^{7} / \mathrm{ml}\right)$

(b) B. stearothermophil us IAM 1035 spores $\left(2.6 \times 10^{7} / \mathrm{min}\right)$

Control (airated sample)

Ozone treated sample
用を示し，オゾン処理を併用することにより殺菌作用が 促進されることを認めた。他の濃度の DADS, DAS に おいてもほほ同様の傾向を認めた。胞子単独時のオンン 処理下での混合に比べて胞子と DADS の通気下での混 合の方か～B. stearothermophilus において殺菌力は減少 したが, B. coagulans においてはほぼ同じになった。 この原因は前報6ににおいても述べたが菌株によるオンン 抵抗力の差巽にあると考えられる。なお DASの場合は， いずれの菌株においても胞子と DAS の通気下の混合よ りも胞子単独時のオソンン処理の方が殺菌力は堌加した。

B. stearothermophilus の場合, B. coagulans に比較 してオソ゚ン抵抗力が弱いためか, DADS, DAS 共存に よるオソンン殺菌の促進効果は認められなかった。耐熱性 のある胞子が栄養細胞になるには少なくとも 3 つの過程 を経ると考えられる。すなわち活性化，発芽，成長がそ れであり活注化は熱や低 $\mathrm{pH}^{18)}$ ，高 $\mathrm{pH}^{14) ， メ ル カ フ ゚ ト ~}$ エタノールやチオグリコール酸のような嗃元绪(13)，極性 の強い溶威であるジメチルフォルムフミドおよびジメチ

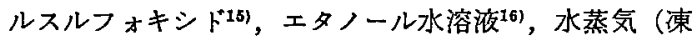
結乾燥した胞子) ${ }^{16)}$, ジピコリン酸カルシウムム ${ }^{17)} と ゙ の$ 処理で起こる。

KEYMAN ら ${ }^{18}$ は活性化は休眠状態の保持状態の保持に 関係しているシスチンに富む Spore coat タンパク質の 3 次構造を変える可逆的な変性であって胞子の透過率の 変化き発芽に関与する酵素タンパク質の活性化ではない かとしている。

発芽は L-フラニン, DL-C-フリルグリシン19), DL-パ

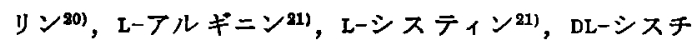

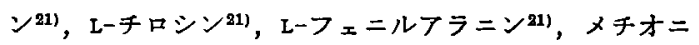

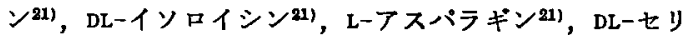
ン21)などのアミノ酸，グルコースなどの糖類 ${ }^{23)}$ ，アデノ シンなどのヌクレオシド21)，カリウムイオント11などの無 機イオンなどの添加で誘導され，この過程は耐熱性を失 う変化であり，またオゾン耐性を失う変化であある。こ れに伴って胞子㮩濁液の O.D. $(600 \mathrm{~nm})$ の低下が認め られる。そこで DADS, DASを添加して B. coagulans 胞子の発芽を検討した結果を Fig. 2 に示す。DADS, DAS はともに胞子の発芽を誘導しその最小濃度はほほ $0.5 \mathrm{mM}$ と考えられる。

しかしその発芽に及ぼす影響は DADSに著しく， DAS の 3〜4 倍の效果を認めた。また DADS 及び DAS の作用部位は Lーアラニンと相乘性を示をず，D-フラニ ンにより阻害されたことから レーアラニンとほほ同じと 考えられる。以上の結果より DADS 及び DAS の共存 


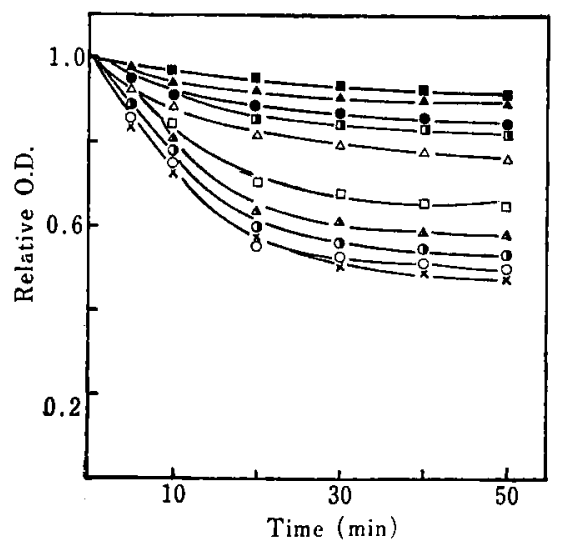

Fig. 2 Germination of $B$. coagulans IAM 1115 spores by DADS and DAS

Heat-shocked spores (about $1.0 \times 10^{7} / \mathrm{ml}$, initial oD $\doteqdot 0.2)$ were inoculated into $\mathrm{Tris}-\mathrm{HCl}$ buffer $(20 \mathrm{mM}$, $\mathrm{pH}$ 7.4) containing $\mathrm{KCl}(0.1 \%)$ at $30^{\circ} \mathrm{C}$,

O; DADS $50 \mathrm{mM}$; $\square, 5 \mathrm{mM}$; 口, $0.5 \mathrm{mM}: \triangle$, ASD

$50 \mathrm{mM}$; $5 \mathrm{mM} ; \triangle, 0.5 \mathrm{mM}$ :, DADS $50 \mathrm{mM}$ plus L-alanine $10 \mathrm{mM} ; \Delta$, DAS $50 \mathrm{mM}$ plus L-alanine $10 \mathrm{mM} ; \times, \mathrm{L}$-alanine $10 \mathrm{mM}: \triangle$. DADS $50 \mathrm{mM}$ plus D-alanine $10 \mathrm{mM}$; DAS $50 \mathrm{mM}$ plus D-alanine $10 \mathrm{mM}$.

下で B. coagulans 胞子のオソ゚ン殺菌力が促進されたの は，DADS 及び DAS の源加により胞子発芽が誘導さ れ，胞子のオゾン耐性が低下した結果と推定される。ま た Lーフラニンは発芽の初期にごく短時間胞子と接解さ せればあとは取り除いても発芽が進行するが， $0.5 \mathrm{mM}$ の DADS 及び DAS の添加でオゾン殺菌効果が認めら れた事実から DADS 及び DAS む L-フラニンと同じよ うな物質であると考えられる。DL-C-フリルグリシンは E. coli, Sacch. cerevisiae の生育を阻害することが知ら れ，その効果はメチオニン，システィンとの反心で除去 することができるとされている28)ところから DADS 及 び DAS 単独添加により通気下で殺菌力が認められたの は，や柱生育を阻害した結果と考えられる。

\section{(2) オソ゚ン処理による DADS, DAS の挙動}

DADS, DAS 共存下のオゾン処理で殺菌カが增加した 原因を追求するため DADS，DAS の消長を検討した。 オソンン処理ガス洗浄瓶内の処理夜中に残存している DADS, DAS をオソン処理時間每に測定した。1例とし て $0.5 \mathrm{mM}$ の DADS, DAS 添加時の結果を Table $2 k$ 示 す。DADS はオソン処理時間の延長に伴いその含量は 低下し，60 分間オソン処理により添加時の約 $1 / 10$ とな った。また DAS はオゾン処理時間の延長に伴いわずか ながら減少したがその含量は 60 分間オソン処理で添加
Table 2 Residual amount of DADS and DAS in Bacillus coagulans spores suspension $\left(1.2 \times 10^{7} / \mathrm{ml}\right)$ by ozone exposure, and final $\mathrm{pH}$ value in that suspension

\begin{tabular}{ccccc}
\hline $\begin{array}{c}\text { Ozone } \\
\text { exposure } \\
\text { (min) }\end{array}$ & $\begin{array}{c}\text { Residual } \\
\text { DADS } \\
\text { (mM) }\end{array}$ & $\begin{array}{c}\text { Final } \\
\text { pH } \\
\text { (DADS) }\end{array}$ & $\begin{array}{c}\text { Residual } \\
\text { DAS } \\
\text { (mM) }\end{array}$ & $\begin{array}{c}\text { Final } \\
\text { pH } \\
\text { (DAS) }\end{array}$ \\
\hline 0 & 0.46 & 5.60 & 0.44 & 5.45 \\
15 & 0.20 & 5.30 & 0.36 & 5.35 \\
30 & 0.10 & 5.10 & 0.34 & 5.10 \\
45 & 0.05 & 4.48 & 0.32 & 5.05 \\
60 & 0.05 & 4.40 & 0.24 & 4.95 \\
\hline
\end{tabular}

Ozone exposure time: $60 \mathrm{~min}$, Initial DADS: $0.5 \mathrm{mM}$, Initial DAS: $0.5 \mathrm{mM}$

時の約 $1 / 2$ となった。処理液の $\mathrm{pH}$ はオゾン処理時間の 延長に伴いいずれる低下した。モノサルファイトは過利 のオソンンによりジフルキルスルホン，フルキルフリルス ルホンに変化することが報告24)されている。BARNARD はジプチルサルフフイド $2 \mathrm{~g}$ を $50 \mathrm{ml}$ の四塩化炭素に 溶解し， $20 \mathrm{mM}$ のオゾンで 75 分間処理することにより 90〜100\% がスルホンになったと報告している。また同 時に C-S 絬合の分裂を意味する微量のアルデヒド及び 酸を認め, この反応は 2 段階に分かれ最初はスルホキサ イドが生成し最後にスルホンになるとした。この原因と してモノサルファイドは分子状酸素には不活性である が，オソンには酸素によるサルフォイドの酸化を触媒す る作用があるかまたは活性化された酸素分子濃度を高好 る作用があり，それらがサルフォイドを酸化するのでは ないかとした。

BOER ら ${ }^{26)}$ はジフルキルサルフォイドのスルホンへの 酸化にはモノサルフォイド1 モルにつき, 1/4 1/3 モル のオゾンを必要とすることを報告している。また MAG・ GIOLO ら ${ }^{27)} 1$ モルのサルフォイドのスルホキサイドへ の酸化には 1 モルのオゾン，スルホンへの酸化には 2 モ ルのオゾンが必要であるとした。今回の DAS の場合， 処瓶理中のーッドスペイスガス及び処理液中にフルデヒ ト，スルホキサイドの生成は認められず，処理液の郝 吸収スペクトルで $\mathrm{C}=0\left(710 \mathrm{~cm}^{-1}\right)$ および $\mathrm{S}=0(1050$ $\mathrm{cm}^{-1}$ ) の吸収は確認できなかった。

オソンン処理による DAS の減少は，処理液の $\mathrm{pH}$ の低 下からみて一部酸化的な変化を受けていると考光られる が，処理猶中のーッドスベイスガス中に DAS が認めら れ，ヨウ化カリウム液の入ったオゾン吸收用ガス洗浄瓶 および空気排出口より DAS 真がしたところからオソ゚ン 化空気を通気中に系外への排出によることが推定され た。なお通気条件下では処理夜の $\mathrm{pH}$ の低下注認められ 
なかったが，DAS 含量の減少を認めた。上記のような 酸化的な変化が少い原因は，オゾン浱度が $0.3 \sim 0.6 \mathrm{mM}$ というような低浱度であるためDASのスルホキサイド， スルホンへの完全酸化には不充分であったためと考えら れる。ジサルフォイドのオソ゚ン酸化生成物はチオスルフ イネート（R・SO・S・R），チオスルフォネート（R・ $\left.\mathrm{SO}_{2} \cdot \mathrm{S} \cdot \mathrm{R}\right)$, ジスルホキサイド (R・SO・SO・R)，シ スルフォン $\left(\mathrm{R} \cdot \mathrm{SO}_{2} \cdot \mathrm{SO}_{2} \cdot \mathrm{R}\right)$ であると報告到されて いる。ジサルフォイドとオゾンとの反応はモノサルフ イドのような段階的な反応ではなく，ジフルキルジサル ファイド1モルの完全酸化には普通 2.5〜3 モルのオゾ ンを必要とする ${ }^{25) 。 ~}$

今回の DADS の場合，反応液の $\mathrm{pH}$ の低下が著しい こと及び残存 DADS 量が少ないことから他の反応生成 物に变化していることが考えられる。しかしガスクロマ ト法によるジフリルスルホキサイド(DADSO) は処理液 中にもへッドネペイスガス中においても検出されなかっ た。また粗ジサルフォイドは分子中に 5 つの酸素原子を 含有しているため水にとけオゾン処理によりスルホン酸 になると考えられる。これらの赤外線吸収スべクトルは 最初，水酸基の吸収は認められないのに約 $1400 ， 1190$ $\mathrm{cm}^{-1}$ に水酸基の吸収が生し $\mathrm{R} \cdot \mathrm{SO}_{2} \cdot \mathrm{O}$ 基の存在を示 すと報告25)されているが，今回の測定ではこれを確認す ることができなかった。なお通気条件下では，処理液の $\mathrm{pH}$ は低下せず，DADS は処理時間の延長に伴い減少の 傾向を示したが大部分は残存した。DADS 液中には一 部 DAS が含有されており（ガスクロマト法により） DAS の影響む考光る必要があると思われる。

2. オゾン殺菌作用に及ぼす共存硫化水素の影響

(1) オゾン処理による硫化水素の殺菌勃果に及活す影 響

硫化水素は, これまでレトルトカマボニ ${ }^{28}(135.2 \mu \mathrm{g} /$ $100 \mathrm{~g})$, レトルトビーフ ${ }^{29)}(209 \mu \mathrm{g} / 100 \mathrm{~g})$, 無菌ビー

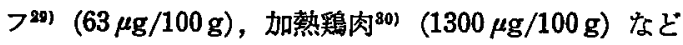
の食品中に異臭として検出されており，いずれる原材料 および製品の加熱処理により生成されることが明らかに されている。また含油食品の場合, 油の酸化進行に伴っ て硫化水素が生成されることが報告されている21)。そこ で今回, 硫化水素の共存下でのオゾン殺菌作用を梌討し た。水溶液中に照濁した胞子 $\left(1.2 \times 10^{7} / \mathrm{ml}\right)$ と各種浱 度 $(20 \mathrm{mM}, 2 \mathrm{mM}, 0.2 \mathrm{mM})$ の硫化水素を混合 $(300$ $\mathrm{ml}$ 容ガス洗浄瓶内）したものを実験方法化記した通気 及びオゾン処理を行った。60分間オソン処理後の結果を Fig. 3 に示した。B. stearothermophilus 胞子単独の場

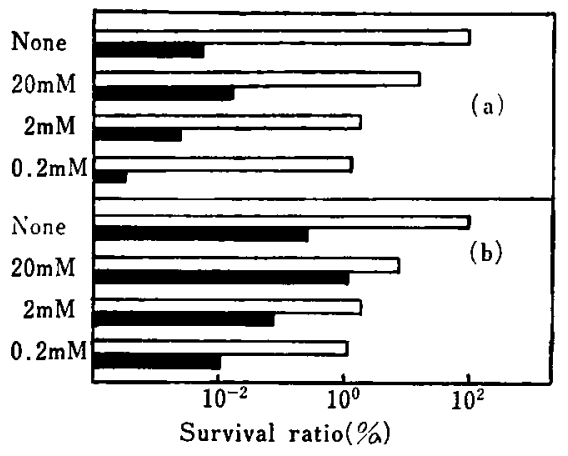

Fig. 3 Effect of hydrogen sulfide on sporicidal activity of ozone

Spores in a test gas wash bottle, spores coexisting with $20,2,0.2 \mathrm{mM}$ of hydrogen sulfide in a vial, and spores suspensions at $20^{\circ} \mathrm{C}$ were treated by ozone of $0.5 \mathrm{mg} / 1$ under a flow rate of $1455 \mathrm{ml} / \mathrm{min}$ for $60 \mathrm{~min}$. and control was airated in the same condition.

(a) B. stearothermobhilus IAM 1035 spores $\left(2.6 \times 10^{7} / \mathrm{ml}\right)$

(b) B. coagulans IAM 1115 spores (1.2× $10^{7} / \mathrm{ml}$ )

$\square$ Control (airated sample)

Ozone treated sample

合，殺菌勃果 $\left(\log \mathrm{N}_{0} / \mathrm{N}\right)$ は 4.15 であるのに対し，胞 子絜濁液に硫化水素 $20 \mathrm{mM}, 2 \mathrm{mM}, 0.2 \mathrm{mM}$ を混合し た通気の場合， $\log \mathrm{N}_{0} / \mathrm{N}$ はそれぞれ $0.68,1.11,1.52$ でありオソン処理の場合はそれそれ 3.69,4.70, 5.30 であった。硫化水素は通気処理においていずれの浱度で む殺菌勃果を示し，オゾン処理を併用することにより $2 \mathrm{mM} ， 0.2 \mathrm{mM}$ の溇度においての及殺菌効果を促進す るととを認めた。B. coagulans 胞子についてもほぼ同 様の傾向を認めた。これらの原因を検討するため $B$. coagulans 胞子を用いて発芽試験を行った結果を Fig. 4 に示す。硫化水素はいずれの浱度においてる胞子の発 芽を誘導しないと考えられる。そこで，20 mM の硫化 水素添加区でオゾン殺菌力が減少し, $2 \mathrm{mM}, 0.2 \mathrm{mM}$ の 硫化水素添加区でオゾン殺菌促進効果が認められた原因 を次のように考えた。後述の反応式より 3 モルの硫化水 素を完全に酸化するには 1 モルのオゾンが必要とされ る。また硫化水素 $2 \mathrm{~g}$ を $60 \mathrm{ml}$ の四塩化炭素に溶解し, $10 \mathrm{mg} / \mathrm{min}$ のオゾンを注入した場合，䄪 40 分で 1〜2 $\mathrm{mg} / \mathrm{min}$ となり，吸収されるオソン量が極めて多いとと が報告821されているところから硫化水素とオゾンとの反 応速度は極めて早いと考えられる。

$20 \mathrm{mM}$ の硫化水素を完全酸化するには 6〜7 mM の オゾンが必要であり，今回のオソン浱度 $(0.3 \sim 0.6 \mathrm{mM})$ 


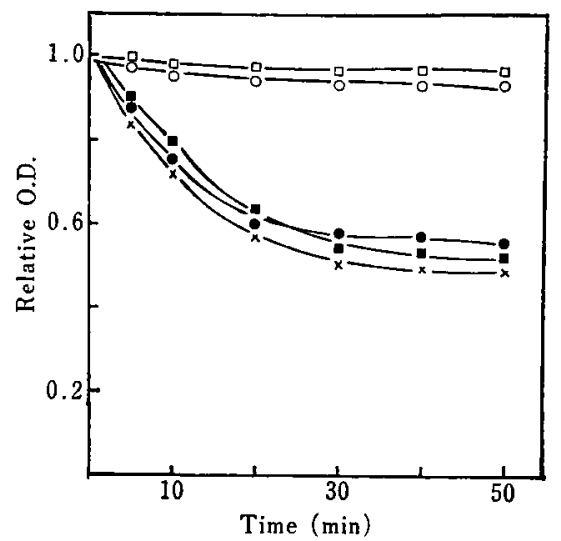

Fig. 4 Germination of $B$. coagulans IAM 1115 spores by hydrogen sulfide

Heat-shocked spores (about $1.0 \times 10^{7} / \mathrm{ml}$, initial $O D=$ 0.2 ) were inoculated into $\mathrm{Tris}-\mathrm{HCl}$ buffer $(20 \mathrm{mM}, \mathrm{pH}$ 7.4) containing $\mathrm{KCl}(0.1 \%)$ at $30^{\circ} \mathrm{C}$.

O. hydrogen sulfide $20 \mathrm{mM} ; \square, 0.2 \mathrm{mM}$;

- hydrogen sulfide $20 \mathrm{mM}$ plus L-alanine $10 \mathrm{mM}$; 0 . hydrogen sulfide $0.2 \mathrm{mM}$ plus L-alanine $10 \mathrm{mM} ; \times$, L-alanine $10 \mathrm{M}$

では完全酸化には不充分で硫化水素に反応するオン゙ン量 は極めて多いと思われる。それに比べて $2 \mathrm{mM}, 0.2 \mathrm{mM}$ の硫化水素の場合はほぼ反応してしまうので残留オゾン 漑度が増加する。(後述の Table 3 参照)

このため，オソン殺菌力が増加したと思われる。さら に硫化水素のオソン反応生成物 (二酸化イオウ ${ }^{82)}$ ) の胞 子に及活寸殺菌効果は大きくないが，水溶液中てオン゙ン と反応することで反応生成物（二酸化イオウ32）により $\mathrm{pH}$ 方低下し(後述の Table 3 参照) オン゙ン殺菌力が 硫化水素埥添区より増大したと考えられる。

なお通気下では硫化水素濃度がいずであっても，短 時間（15分以内）に反応瓶より排出されるため, 殺菌作 用は認められたが硫化水素濃度による殺菌力の差は，才 ゾン処理区ほど認められなかった。

(2) オゾン処理による硫化水素の挙動

硫化水素共存下のオン゙ン処理で殺菌力が変化した原因 を追求するため硫化水素の消長及び反応生物について椧 討を行った。園田ら ${ }^{82}$ は四塩化炭素を溶媒として, 硫化 水素及び元素イオウのオゾン処理を行い，多量の二酸化 イオウの発生を認めたが, 四塩化炭素溶液中にはオゾン 化生成物質を認めていない。そこで処理時間毎にーッド スペイスガス中の含酼化合物它測定し，その結果をFig. 5 に示した。へッドスペイスガス中に硫化カルボニル及 び硫化水素を検出したが二酸化イオウは認められなかっ

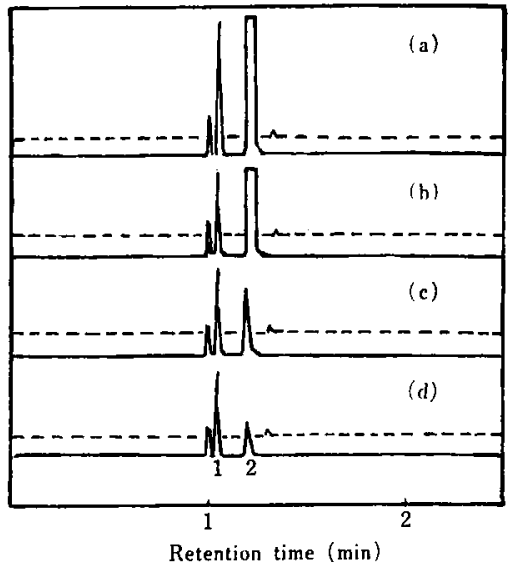

Fig. 5 Gas chromatographic profiles of volatile compounds produced by ozone exposure in $20 \mathrm{mM}$ of hydrogen sulfide solution

Ozone exposure condition

$20 \mathrm{mM}$ of hydrogen sulfide solution at $20^{\circ} \mathrm{C}$ were treated by ozone of $0.5 \mathrm{mg} / \mathrm{l}$ under a flow rate of $1455 \mathrm{ml} / \mathrm{min}$ for (a) $15 \mathrm{~min}$, (b) $30 \mathrm{~min}$, (c) $45 \mathrm{~min}$. (d) $60 \mathrm{~min}$.

Peak are 1 carbonyl sulfide, 2 hydrogen sulfice - FPD -.- FID

た。 $20 \mathrm{mM}, 2 \mathrm{mM}, 0.2 \mathrm{mM}$ の硫化水素を共存させた 場合, オゾン処理 15 分, 30 分, 45 分, 60 分々処理時間 が延長するに伴い硫化水素は著しく減少した $(20 \mathrm{mM}$ : $1.26 \mathrm{mM}, 1.00 \mathrm{mM}, 0.204 \mathrm{mM}, 0.110 \mathrm{mM} ; 2 \mathrm{mM}$ : $0.116 \mathrm{mM}, 0.091 \mathrm{mM}, 0.067 \mathrm{mM}, 0.017 \mathrm{mM} ; 0.2 \mathrm{mM}$ : $0.071 \mathrm{mM}, 0.052 \mathrm{mM}, 0.031 \mathrm{mM}, 0.005 \mathrm{mM}$ )。し加 し硫化カルボニルは 15 分間処理で生成し 30 分間処理で やや減少したが 60 分間処理まで一定した含量を認めた。

この硫化カルボニルは含油食品の香気成分中検出さ れ，サラダ掛米荣, 溉粉あられ，ポテトチッブ，バウム クーヘン,フライビーンズの上うな酸化をしやすい食品 に多く生成するととが報告881されている。今回の実験は 水溶液中で行っているため酸化生成された二酸化イオウ は水溶液に溶存し硫化カルボニルのみがーッドスベイス ガス中に検出されたと思われる。二酸化イオウの生成性 処理夜の $\mathrm{pH}$ の著しい低下により明白で Table 3 に 1 \%炭酸カドミウム液化吸収された硫化水菜量並び伐留 オソ゚ン摆度とともに示した。硫化水素は一部 $3 \mathrm{H}_{2} \mathrm{~S}+\mathrm{O}$ $\rightarrow 3 \mathrm{H}_{2} \mathrm{O}+3 \mathrm{~S}$ のごとく反応 ${ }^{84)}$ 乙完全に分解するととが 知られているが，この元素イオウがオソンンにって酸化 されれば二酸化イオウが，オソンによって酸化生成され たカルボニル基と反応すれは硫化カルボニルができると 
Table 3 Residual amount of ozone in Bacillus coagulans spores suspension (1.2X $10^{7} / \mathrm{ml}$ ) and residual amount of absorbed hydrogen sulfide in $1 \% \mathrm{CdCO}_{3}$ solution, and final $\mathrm{pH}$ value in that spores suspension

\begin{tabular}{cccc}
\hline $\begin{array}{c}\text { Initial hydro- } \\
\text { gen sulfide } \\
\text { concentration } \\
\text { (mM) }\end{array}$ & $\begin{array}{c}\text { Final } \\
\text { pH }\end{array}$ & $\begin{array}{c}\text { Residual } \\
\text { ozone } \\
\text { (mg/100 ml) }\end{array}$ & $\begin{array}{c}\text { Absorbed } \\
\text { hydrogen } \\
\text { sulfide } \\
\text { (mM) }\end{array}$ \\
\hline 20.0 & 2.20 & 0.144 & 2.870 \\
2.0 & 2.90 & 0.480 & 0.230 \\
0.2 & 3.80 & 0.720 & 0.024 \\
\hline
\end{tabular}

Ozone exposure time: $60 \mathrm{~min}$, residual hydrogen sulfide in spores suspension was not detected. Absorbed sulfur dioxide in $3 \% \quad \mathrm{H}_{2} \mathrm{O}_{2}$ solution also was not detected.

考えられる。

$$
\text { 要 約 }
$$

オゾン殺菌における共存ジアリルジサルフォイド (DADS)，ジフリルサルフォイド (DAS), 硫化水素の影 響について B. coogulons IAM 1115 及び B. stearothermophilus IAM 1035 の胞子它供試して検討を行っ た。その結果，

(1) B. coagulans 胞子が DADS, DAS と通気下で 共存するだけでる殺菌効果を示し，オソン処理を併用す ることにより著しい殺菌効果が出現した。しかし $B$. Stearothermophilus 胞子については著しいオゾン殺菌 促進勃果は認如なかった。

（2）殺菌促進効果を示した DADS, DAS は胞子の発 芽誘導物質であることを認め，盷子の発芽が DADS， DAS により誘導されるためにオソン殺菌力が堌大した と考えた。

(3) $20 \mathrm{mM}$ の硫化水素共存下では保護钦果を示し, $2 \mathrm{mM}, 0.2 \mathrm{mM}$ では殺菌促進勃果を示した。この原因 は, オソンンと硫化水素の反応に基つく残留オゾン量の差 異並びに二酸化イオウ生成による $\mathrm{pH}$ の低下と考えた。

\section{文献}

1) Yang, P.P.W. and Chen, T.C.: J. Food Sci., 44, 501 (1979).

2) Dickerman, J. M., Castraberti, A. O. and FULlER, J.E.: J. New Engl. Water Works Assn., 68, 11 (1954).

3) O'Donowan, D.C.: J. Amer. Water Works Assn., 57, 1167 (1965).

4) Gabovich, R. D.: Chem. Absrt., 65, $5219 \mathrm{H}$ (1966).

5) Sмiтh, W.W. and Bodkin, R.E.: J. Bacteriol., 47, 445 (1944).

6）内藤茂三・志賀一三：日食工誌，29，1（1982）
7) Doid, H. and Knapp, A.: World Med., 6, 272 (1949).

8) Cavallito, C. J. and Bailey, J.H.: J. Am. Chem. Soc., 66, 1950 (1944).

9）JIS K 0102，環境庁告示第 9 号（昭和 47 年 5 月 30 日)

10) Pokorny, J.: Chem. Prumysl., 14, 265 (1964).

11) ZUKERMAN, I.: Nature, 168, 517 (1951).

12) Frazier, W.C.: Food Microbiology, (McgrawHill Book Co., Inc., New York, Toronto, London) p. 140 (1958).

13) Keynan, A., Evenchik, Z. and Halvorson, H. O.: J. Bacteriol., 88, 313 (1964).

14) GibBs, P.A.: J. Gen. Microbiol., 46, 285 (1967).

15) Widdowson, J.P.: Nature, 214, 812 (1967).

16) Hyatr, M.T. and Levinson, H.S.: J. Bacteriol., 95, 2090 (1968).

17) LEE, W.H. and ORDAL, Z.J.: J. Bacteriol., 85, 207 (1963).

18) Keynan, A., Issahary-Brand, G. and EvenchiK, Z.: Spore III Ced. Campbell, L. and HaLvorSON, H.O.) p. 180 (1965).

19) Irie, R., Окамото, T. and Fujta, Y.: J. Gen. Appl. Microbiol., 26, 425 (1980).

20) WoEse, C.R., MoRowjtz, H.J. and Hutchinson, C.A.: J. Bacteriol., 76, 578 (1958).

21）蜂須賀養悦: 化学之生物, 7, 509 (1969).

22) Church, B.O., Halvorson, H. and Halvorson, H.O.: J. Bacteriol., 68, 393 (1954).

23) DitTmer, K.: Ann. N. Y. Acad. Sci, 52, 1274 (1950).

24) Price, C.C. and Bullitt, O.H.:J. Org. Chem., 12, 238 (1947).

25) Barnard, D.: J. Chem. Soc., 4547 (1957).

26) Bozr, H. and Kooyman, F.C.: Anal. Chim. Acta, 5, 550 (1951).

27) Mogglolo, A. and Blair, E. A.: Advances in Chemistry Series, 21 (American Chemical Society, Washington) p. 200 (1959).

28）山沢正勝・村頛 誠 $\cdot$ 志賀一三：日水誌，46,187 (1979).

29) Luh, B.S., Gonzalez-Acuna, C.G., Leonard, S. and Simone, M.: Food Techol., 96, 218 (1964).

30) Mecch, E.P., Pippen, E.L. and Lineweaver, H.: J. Food Sci., 29, 393 (1964).

31）内藤茂三：票知食工試年報，20，85 (1979).

32）園田 昇・松村尚武・是好德享・堤 繁：工化 誌, 72, 1099 (1969).

33）内藤茂三 - 大島克己 - 石田欽一・清水喜和：舜知 食工試年報，20，77 (1979)。

34) Eulis, C.: The Chemistry of Petroleum Derivatives (Reinold Pub.) (1937).

(昭和 56 年 5 月 2 日受理) 